\title{
RECEPTION AS A GENERAL LEGAL AND CONSTITUTIONAL LEGAL PHENOMENON
}

\section{Verlos N. V.}

\section{INTRODUCTION}

In the current conditions of internationalization and globalization of all spheres of life of the world society, which is being formed under the influence of many factors: social, political, economic, historical, scientific and technical, geographical, climate, etc. - there is an irreversible tendency towards gradual convergence (cohesion, interpenetration) of legal systems.

Of course, legal systems have never existed autonomously, but "trade turnover of the legal ideas" ${ }^{1}$ has increased dramatically in the recent decades, and migration of legal norms is undoubtedly the "most common form of legal changes" $^{2}$. Constitutional law does not stay apart from this process, and the Constitution itself is a systematic matrix within which the goals of state building and the basic vectors for the development of constitutionalism are set.

The modernization of the constitutional dimension of the functioning of the modern democratic state, the solution of the global problems of the humanity through the establishment of an international (transnational) constitutional legal order requires a thorough analysis and a balanced approach in view of the problems of regulatory legitimacy. The problems of the sort may arise referred to the formation of an organized system of crossconstitutional clusters.

The main threat to this process may be the reception under the auspices of the transnational (international) constitutionalism of normative models without taking into account national legal traditions, features of constitutional culture as well as national mentality. Which in its turn can cause a legal mutation, a distortion of constitutional justice, a loss of national identity and, ultimately, a loss of state sovereignty. However, despite the threats and fears, there is an innovative potential in the design of interconstitutional (trans-constitutional) relations, which is to combine the constitutional configurations of national, international and European levels.

Under the influence of these factors, the legal system of Ukraine is being transformed, also accompanied by a dynamic process of reforming of the legislative system. For the balanced functioning and development of the

\footnotetext{
${ }^{1}$ Kahn-Freund O. On Uses and Misuses of Comparative Law. The Modern Law Review. 1974. Vol. 37, № 1 (Jan.). P. 10.

${ }^{2}$ Watson, A. Legal Origins and Legal Change, London ; Rio Grande, Ohio, USA : Hambledon Press, 1991. P. 73.
} 
Ukrainian statehood, the key priority is to carry out a systematic constitutional and legal modernization in accordance with the foreign policy vector of the European and Euro-Atlantic development of Ukraine, determined in accordance with the changes in the preamble to the Constitution of Ukraine of February 7, 2019 ${ }^{3}$. Moreover, this process is accompanied by the reception of the certain ideas, concepts, doctrines, institutes and norms in the constitutional law of Ukraine in general and the Constitution in particular. Today, research into the problem of reception in the constitutional law of Ukraine is an urgent need, and it requires the establishment of the doctrinal definition and development of a qualitatively updated concept of the state construction.

\section{Reception as a scientific category}

Systematic research and formation of a holistic view of the reception in constitutional law as a political and legal phenomenon requires analysing, first of all, the semantics and etymology of the term "reception". Since the term has been widely used in the scientific discourse, not only in legal science, but also in philology, cultural studies, psychology, literature, linguistics, music, history and others.

The term comes from lat. "receptio" - a reception, a perception, but there is no unambiguous interpretation in the reference literature, so, some dictionaries offer to understand it as "borrowing and adaptation by a society of the sociological cultural forms that have arisen in another country or in another era" ${ }^{4}$. Another vocabulary of foreign words and expressions suggests considering the term as "the perception of the legal system and principles of another state as the basis of national law" ${ }^{5}$. The newest vocabulary of foreign words and expressions interprets the term "reception" in three meanings: 1) the borrowing by the society of sociological and cultural forms that have arisen in another country or in another era; 2) borrowing from one state more developed law of another state; 3) transformation of energy of stimuli on nervous excitations carried out by receptors of perception ${ }^{6}$.

The content of the term "reception" also differs in the branch research. In psychology, in particular, the term is considered a process of physiological display of a physical stimulus in the receptor, which can obtain in the central part of the analyser the systemic quality of a subjective image or experience,

\footnotetext{
${ }^{3}$ Конституція України від 28 червня 1996 p. URL: https://zakon.rada.gov.ua/ laws/show/254к/96-вр.

${ }^{4}$ Словарь иностранных слов. 18-е изд., стереотип. М. : Рус. яз., 1989 . С.444. Словник української мови : [в 11 т.] / [ред. кол.: І.К. Білодід (гол.) та ін.] ; АН УРСР, Ін-т мовознавства ім. О.О. Потебні. К.: Наукова думка, 1970-1980. Т. 7. 1976. С. 521.

${ }^{5}$ Новейший словарь иностранных слов и выражений. Мн.: Совр. лит., 2007. С. 701.

${ }^{6}$ Словник іншомовних слів /За ред. О. С. Мельничука. Київ : Головна редакція УРЕ, 1974. C. 675.
} 
and only through this, it can become a psychic reflection in the forms of pain, sensation and perception ${ }^{7}$. Another psychological dictionary interprets the term as the process of perception and transformation of energy of various stimuli (mechanical, thermal, chemical, etc.) of the outside world into nerve signals ${ }^{8}$.

In literature studies, the reception is understood by some researchers as "... the process of borrowing and adapting to a particular society different cultural texts that have arisen in different countries during different epochs" 9 . According to A. A. Goncharuk, the receptive approach is to consider the work not to be an artistic value that exists in itself, but a component of the system in which it interacts with the recipient. And as a result, the work is not researched as a historically open phenomenon, the value and meaning of which are historically transferred, variable and amenable to rethinking. Others, for example, Khamedova O. B. defines reception as "... a way of perceiving and understanding (processing, comprehending) creativity..." ${ }^{10}$. M. M. Levakin proposes to understand the artistic reception as "perception and reproduction on the basis of perceived (read, experienced, seen, realized) own texts (thoughts, ideas, impressions, paintings), i.e., in fact, the reception according to the researcher is a form of perception"11. The term reception is also actively used in linguistic research, for example, Simonok V. P. consider the lexico-semantic reception to be borrowing and the gradual adaptation of foreign language elements to the new system of the recipient language ${ }^{12}$. Pidkaminna L. V. considers the reception as a dynamic process of re-creation by the reader of the aesthetic landmarks embedded in the poetic text by the author ${ }^{13}$. This process is relatively limited both by the text itself (and implies mandatory intersubjective agreement) and by the individual characteristics of the reader as well as the cultural aspect that determines the coordinates of the reception.

${ }^{7}$ Бродовська В. Й., Грушевський В. О., Патрик І. П. Тлумачний російсько-український словник психологічних термінів: словник. - К.: ВД «Професіонал», 2007. Р. 308.

${ }^{8}$ Психологічний словник /[авт.-уклад.: В. В. Синявський, О.П.Сергєєнкова ; за ред. Н.А.Побірченко. К.: Наук. світ, 2007. С. 258.

${ }^{9}$ Гончарук Р. А. Читацька рецепція як складова літературної комунікації. Наукові записки нду ім. М. Гоголя. Філологічні науки. 2016. Книга 2. С. 28.

${ }^{10}$ Хамедова О. Б. Антоненко-Давидович : доля, творчість, критична рецепція : автореф. дис. ... канд. філол. наук : 10.01.01. Харків, 2008. 20 с.

11 Левакин Н.Н. Художественная рецепция как литературоведческое понятие (к вопросу понимания термина). Известия ПГЛУ им. В.Г. Белинского. 2012. № 27. С. 309.

12 Сімонок В. П. Лексико-семантична рецепція іншомовної лексики в українській мовній картині світу. Автореферат дисертації на здобуття наукового ступеня доктора філологічних наук за спеціальністю 10.02.01. Харків, 2002. 25 с.

${ }^{13}$ Підкамінна Л.В. Епітет Т.Г. Шевченка: генеза, структура і сучасна мовна рецепція. Автореферат дисертації на здобуття наукового ступеня кандидата філологічних наук за спеціальністю 10.02.01. Київ, 2011. С. 10. 
T. V. Poliashenko in the study of art studies analyses the reception of the Ukrainian customary law, understanding its historical evolution within the implementation of the customary law in the culture of Ukraine XX - XXI centuries and its influence on the development of Ukrainian artistic culture $^{14}$. Letina M. M. defines the term as "an episodic ... conscious borrowing of ideas, materials and motives considered as the samples to adapt them to own aesthetic, ethical, political and other interests" ${ }^{15}$.

Pedagogical science interprets the reception as an intellectual process of perception of a scientific concept, which occurs through its reconstruction, analysis and criticism ${ }^{16}$.

In the art of music, Ya. Oleksiv emphasizes the understanding of the reception in the context of the restoration of musical genres of the past in other historical conditions, " ... their revival and rethinking ..." ${ }^{17}$.

S. F. Oliynyk also believes that the term "reception not only denotes the fact of aural perception of a composer's work or works. But it also includes certain activities and actions that make the recipients to het a spiritual response to the creative heritage of a certain composer and that are documented or evidenced, and thus they can influence to promote composer creativity in the society"18. In other words, the researcher characterizes the reception as a process of perception and assimilation.

Representatives of historical science emphasize the need to understand the reception as "... the process of perception and interpretation of national history ... and the impact of these scientific and historical interpretations on the process of national self-identification ..." ${ }^{19}$. In philosophy, the reception is also equated with "perception and modification"20.

The study has shown that the term reception is widely used in the natural sciences and humanities; however, there is no fixed or uniform terminological

14 Поляшенко Т.В. Рецепція звичаєвого права в сучасній українській культурі. дисертація на здобуття наукового ступеня кандидата культурології за спеціальністю 26.00.01. Київ, 2009. 17 с

15 Летина Н.Н. Теоретические основания рецепции в провинциальном искусстве. Регионология. 2008. № 3. С. 295.

${ }^{16}$ Міхно О. Типологія школярів Петра Лесгафта та їі рецепція українськими вченими. Рідна школа. 2016. № 7. С. 61-68.

${ }^{17}$ Олексів Я. Рецепція жанрів сюїти і партити в українській баянній музиці другої половини ХХ ст. : автореф. дис. ... канд. мистецтвознав. : 17.00.03 Львів, 2011. С. 3.

${ }^{18}$ Олійник С. Ф. Регіональна рецепція музичної творчості (на прикладі творчості Ф. Шопена, Р. Вагнера і Ф. Ліста в музичній культурі Львова) Дисертація на здобуття наукового ступеня кандидата мистецтвознавства за спеціальністю 17.00.03. Львів, 2018. С. 39.

19 Куций І.П. Українська науково-історична думка Галичини (1830-1894рр.): рецепція національної історії. Тернопіль: Джура, 2006. 220 с.

20 Мотренко Т. Рецепція гегелівських ідей у світоглядно-релігійній парадигмі російської філософії XIX - початку XX століть : автореф. дис. ... д-ра філос. наук : 09.00.05. K., 2004. $37 \mathrm{c}$. 
understanding, which complicates the use of the term to specify certain phenomena or processes. However, there is a large number of $\mathrm{PhD}$ theses in various fields of humanities and the authors use the term "reception" in the names of the works. Nevertheless, the authors do not provide a clear definition of the term, understanding of which impliedly influence the general nature of the study, and therefore the perception of its content depends mainly on interpretation and imagination of the acceptor. In particular, the analysis of the use of the category "reception" in various fields of science allows to determine the main qualitative characteristics of this phenomenon, namely, it is used in the understanding: "borrowing and adjustability", "borrowing and adaptation", "perception", "perception and transformation", "perception and comprehension", "perception and assimilation", "perception and interpretation", "perception and modification", "revival and rethinking". These findings suggest that there are four basic semantic characteristics of understanding the phenomenon under study: 1) borrowing; 2) revival; 3) perception; 4) mastering (adaptation, adaptation, modification, interpretation, etc.).

\section{Reception as a common law phenomenon}

In jurisprudence, there is no unity of doctrinal approaches to understand the term "reception of law", although it has a long history of use. In legal dictionaries, encyclopaedias, and other reference literature, "reception of the law" is defined as "borrowing and adjusting to the conditions of any state a law developed by another state or in a previous historical era" ${ }^{21}$ or "... the process of interaction, borrowing, perception of any domestic law system of principles, institutions, basic features of another domestic (national) legal system" ${ }^{22}$. There is also an ambivalence in understanding the reception of law, namely in broad and narrow sense. At the same time, in broad sense, the reception of law is the conscious borrowing and mastering of the assets of another's culture for enriching domestic culture. In addition, in narrow sense, the use of the Roman law system in some countries of Western Europe, especially in Germany, since the 12th century, which peaked in the 15-16 centuries ${ }^{23}$.

Therefore, before deciding on the legal nature of reception in modern constitutional law, it is worth considering the doctrinal approaches to this phenomenon used in other branches of legal science. A well-known scientist in the field of comparative jurisprudence A. Kh. Saidov argues that the reception is the restoration of the action (selection, borrowing, processing

\footnotetext{
${ }^{21}$ Большая советская энциклопедия. Под ред. А. М. Прохорова. М.: Изд-во «Советская энциклопедия», 1975. Т. 22. С. 67.

22 Большой юридический словарь. Додонов В. Н., Ермаков В. Д., Крылова М. А. и др. М.: 2001. С. 476; Словарь международного права [С. Б. Бацанов, Г. К. Ефимов, В. И. Кузнецов и др.]. 2-е изд. М.: Международные отношения, 1986. С. 356.

${ }^{23}$ Тихомирова Л. В., Тихомиров М. Ю. Юридическая энциклопедия. М., 2002. С. 757. 
and assimilation) of the normative, ideological and theoretical content of Roman law, which proved to be suitable for regulating new relations that are higher degree of social and legal development. However, at first, this reception was doctrinal: Roman law was not directly used, its conceptual fund, a sufficiently developed structure, internal logic and legal technique were studied. Ultimately, the reception of Roman law led to the fact that even in the Middle Ages, the legal systems of European countries - their legal doctrine, legal technique - gained some similarities ${ }^{24}$.

Although there is a contrary opinion in the legal literature, expressed by F. Wieacker ${ }^{25}$ and supported by V. Tomsinov, who believes that "... the phenomenon, which was called in the legal literature as the reception of Roman law in Western Europe in the Middle Ages" was not really the reception ${ }^{26}$.

Researcher of Roman law A. I . Kosarev notes that during the reception process, there was a complement of less developed legal systems with the experience of a higher status. Over time, there was their partial incompatibility and alienation, which was not consistent with the existing standards of national life and fundamental principles, traditions of their own law (as it was in the Middle Ages with the knowledge of Roman law, obtained by "elegant lawyers" ${ }^{27}$ ). That is why, in his opinion, reception is not a mechanical transfer, but a complex (and multi-stage) process of borrowing based on selection, then processing according to the certain conditions, finally, assimilation, when foreign becomes an organic part of national right. The struggle of the new with the old, the victories of the new, the defeats, the victories again were determined by the multistage of the reception process. Finally, in the early stages of the bourgeois society, Roman law was perceived as it was $^{28}$.

Modern domestic researcher L. V. Shala also regards the reception of Roman law as the process of transferring, adapting, rooting, preserving and using of historically perfect ideas, principles and norms by the legal systems to regulate public relations on private property ${ }^{29}$.

${ }^{24}$ Саидов А.Х. Сравнительное правоведение (основные правовые системы современности): учебник. Под ред. В.А. Туманова. М.: Юристь, 2003. 448 с.

${ }^{25}$ Wieacker F. The importance of roman law for western civilization and western legal thought. Boston College International and Comparative Law Review. 1981. Vol. 4. № 2. P. 270.

${ }^{26}$ Томсинов В. А. О сущности явления, называемого «рецепцией римского права» / в кн. Виноградов П. Г. Очерки по теории права. Римское право в средневековой Европе / Под редакцией и с биографическим очерком У. Э. Батлера и В. А. Томсинова. М.: Издательство «Зерцало», 2010. С. 279.

27 «Елегантними юристами» називають осіб, що займаються історією римського права.

${ }^{28}$ Косарев А.И.. Римское частное право. М.: Юриспруденция, 2007. С. 177.

${ }^{29}$ Шала Л. В. Концепція приватної власності у римському праві та ії рецепція у праві України. Автореф. дисертації на здобуття наукового ступеня кандидата юридичних наук за спец. 12.00.01, Львів, 2010. 19 с. 
The exclusively historical aspect of the reception is emphasized by domestic researchers of Roman law O. A. Pidoprigora, E. O. Kharytonov. They define the reception as the process of revival of Roman law, perception of the spirit, ideas and main principles and basic provisions of the civilization at a certain stage of its development in the context of the general process of cyclical renaissances ${ }^{30}$. Another researcher F. D. Finochko interprets the reception of Roman law as the acceptance of sources, mainly in the Middle Ages, the basic principles of Roman law ${ }^{31}$.

The representative of the Russian legal science K. M. Denisova argues for the need to understand the reception as the process of perception, the transformation of the system of Russian law from socialist to RomanoGerman legal system based on the reception of Roman law "as a common ancestor of European - Roman law is a theoretical expression of the genetic community of legal development. In addition, in her opinion, the secret to the longevity of Roman law is that the Romans learned to perceive and synthesize creatively not only their own but also others' experiences ${ }^{32}$.

Consequently, the representatives of theory of state and law traditionally consider "the reception" as a universal phenomenon through the prism of the reception of Roman law, and it is understood mainly as the process of revival of Roman law in modern legal relations, which consists in borrowing, perception, selection and adaptation, etc. At the same time, understanding the reception of law exclusively through the study of the evolution of Roman law influence on European legal systems does not reflect the essence of this general theoretical phenomenon.

Concurring with N. V. Parshkova, who denies reducing the understanding of the reception exclusively to the reception of Roman law, arguing that the processes similar to the medieval reception of Roman law, took place in the Far East, where Chinese law was the source of the reception ${ }^{33}$. Other examples include borrowing from the Scandinavian legal systems of German commercial and commercial law, the formation of a Europeanized secular component by the Japanese legal system ${ }^{34}$.

${ }^{30}$ Підопригора, О.А., Харитонов, С.О. Римське право : підруч. 2-ге вид. К. : Юрінком Інтер, 2009. C. 130.

${ }^{31}$ Фіночко Ф. Д. Роль рецепції римського права у формуванні європейських традицій адміністративного права Вісник Харківського національного університету внутрішніх справ. 2007. № 38. C. 24-31. URL: http://nbuv.gov.ua/UJRN/VKhnuvs_2007_38_6.

32 Денисова Е.М. Проблема рецепции римского права в России. Вестник ТвГУ. Серия. Право. 2012. Вып.32. С. 328-329.

${ }^{33}$ Паршкова Н.В. Определение преемственности в рецепции права: общетеортетический аспект. Вопросы современной юриспруденции: сб. ст. по матер. VIII междунар. науч.-практ. конф. - Новосибирск: СибАК, 2012. URL: https://sibac.info/conf/law/viii/26094.

${ }^{34}$ Егоров А.В. Сравнительное правоведение и правовая рецепция. Вестник Полоикого государственного университета. Серия D. Экономические и юридические науки. 2013. № 6. C. 164 . 
Modern representatives of the theory of state and law and comparative jurisprudence have departed from the interpretation of the reception solely in understanding the perception or revival of the system of Roman law, but there are studies in which it is still interpreted within historical context.

Domestic researchers E. Kharytonov and O. Kharytonova insist that according to the origin of the term "reception", it is justified to use it precisely in cases of revival, perception of spirit, categories, principles, concepts and basic provisions of the law. All these was formed by the previous civilizations and considered by the subsequent civilizations in a particular stage of development and in the context of general process of cyclic revival $^{35}$. In addition, scientists emphasize that this approach should not be about "interaction" of legal systems but about "continuity of law - the impact of one legal system on another". Besides they claim "... the extension of this concept is not justified because it is related to a violation of the Occam blade principle" ${ }^{\prime 36}$. Z. M. Chernilovskyi also considers the reception to be only a transition of norms from the legal system of one formation to the legal system of another ${ }^{37}$.

Giving the due to the supporters of the traditional understanding of the reception of law, we believe that it is necessary to take into account the modern realities in which the rapid development of social relations and the relentless process of internationalization of law. Thus, there is a need for the development and improvement of classical, traditional doctrines, as well as for expanding the content legal categories in the legal science. That is, in this we have a fully justified semantic rethinking of the category "reception" in terms of adapting it to the modern needs of legal reality and legal science.

The German scientist F. Wieacker does not rule out the possibility of use of the term "reception" to describe the perception of Roman antiquity by Southern Europe in the early Middle Ages or its perception in Northern Europe a little later. The scientists insists on the need to expand its content and believe that "... it is correctly to use the term "reception" in the case of the adoption of one legal order by another legal order, which is contemporary to the first one, for example, the "reception" of Civil Code of Switzerland by Turkey" ${ }^{38}$.

35 Харитонов Є., Харитонова О. Від осмислення рецепції римського права - до формування загальної теорії взаємодії правових систем. Право України. 2014. С. 280; Харитонов Є.О. Методологічні засади дослідження проблем правової адаптації України до внутрішнього ринку ЄС. Наукові пращі Наџіонального університету "Одеська юридична академія». Т. 17 / голов. ред. М.В. Афанасьєва; МОН України, НУ «ОЮА». Одеса : Юрид. л-ра, 2015. С. 242.

36 Харитонов Є., Харитонова О. Від осмислення рецепції римського права - до формування загальної теорії взаємодії правових систем. Право України. 2014. С. 280.

${ }^{37}$ Черниловский 3.М. Русская Правда в свете других славянских судебников. Древняя Русь: проблемы права и правовой идеологии : Сб. науч. тр. М.: ВЮЗИ, 1984. С. 3-35.

${ }^{38}$ Wieacker F. The importance of Roman law for western civilization and western legal thought. Boston College International and Comparative Law Review. 1981. Vol. 4. № 2. P. 270. 
Researchers characterize the "reception of the right" solely as borrowing or borrowing and perceiving of the legal material of one legal system by another, but still the interpretations differ.

A number of scholars have emphasized that the interpretation of the reception solely as legal borrowing (or one of its forms). V. I. Lafitskyi notes, "... reception is a mechanism for voluntarily borrowing of the most effective legal models of other states" ${ }^{39}$. Researching the problem of legal borrowing, A. V. Skorobogatov proposes to classify them into several groups: 1) reception of law; 2) legal dialogue; 3) legal acculturation; 4) legal transfer and 5) legal expansion ${ }^{40}$. In other words, the researcher actually attributes the reception to the legal borrowing group and accepts it as a borrowing of the legal norms, principles and values of the donor society, with further adaptation to the conditions of the national legal family of the recipient society. At the same time, revealing the concept of legal acculturation, the author almost duplicates it with the reception, because in both cases he emphasizes "... the need to assimilate the legal norms and legal values of the donor society..." ${ }^{41}$.

$\mathrm{Yu}$. M. Folgerova also understands the reception as the process of borrowing from one state of the experience of legal regulation for the national legal system of another state (states) ${ }^{42}$. V. O. Tomsinov believes that the process of perception in a particular state of the elements of the legal system of another state is called "reception of right" ${ }^{43}$.

Another scientist L. V. Avramenko also argues for such a position and believes that the reception should be considered as "... perception - transfer, storage and use" 44 . In addition, the scientist concludes that "... reception" and "succession" are close in meaning categories that can be used interchangeably".

A rather large group of scholars advocate an expanded interpretation of the concept of reception as the process of borrowing and perceiving the law of one state by another.

39 Лафитский В.И. Сравнительное правоведение в образах права. Том первый. М.: Статут, 2010. С. 113.

${ }^{40}$ Скоробогатов А. В. Правовые заимствования как средство совершенствования национальной правовой системы. Актуальные проблемы экономики и права. 2018. Т. 12. № 1. C. $77-88$.

${ }^{41}$ Ibid. C. $80-81$.

42 Фольгерова, Ю. Н. Преемственность и рецепция в конкурсном процессе стран Западной Европы и России: Историко-сравнительный анализ: автореф. дис. на соискание уч. степени канд. юр. наук. спец 12.00.01. Саратов, 2008. С. 7.

${ }_{43}$ Томсинов В. А. О сущности явления, называемого «рецепцией римского права»/ в кн. Виноградов П. Г. Очерки по теории права. Римское право в средневековой Европе / Под редакцией и с биографическим очерком У. Э. Батлера и В. А. Томсинова. М.: Издательство «Зерцало», 2010. С.2 64.

${ }^{44}$ Авраменко Л.В. Розмежування наступності у праві з іншими суміжними поняттями. Проблеми законності. 2012. № 121.С. 5. 
In particular, E. Yu. Kuryshev proposes to define the reception of right as a phenomenon involving the processes of perception, repetition and borrowing of a right produced in another state (legal system). The socioeconomic conditions of the states are similar because of the historical continuity and connection of the legal culture of countries ${ }^{45}$. G. M. Aznagulova argues for a similar position: "Reception is the basic form of interaction of national legal systems and it can be understood as a process of perception and adaptation to the conditions of any state of law, produced in another state or in a previous historical epoch" 46 .

I. M. Mutai believes that reception is the process of bringing to the legal system of the state the legal norms that originally belonged to the legal system of a foreign state or a donor state ${ }^{47}$. As I. M. Sharkova notes, "not excluding the possibility of using the concept of reception in the study of problems of European legal integration, it is necessary to remember the cultural and historical continuity in the interaction of legal systems. Forgetting continuity, ignoring the cultural and legal context of the development of modern legislation in Romance studies is defined by another concept - "vulgarization of the law" ${ }^{48}$. Another researcher Prieshkina O. O. points out that "the reception of law is a complex phenomenon, which includes processes of succession, perception, repetition and borrowing of the right made in another state (legal system) by virtue of the historical continuity and connection of the legal culture of the states, socio-economic conditions in which are similar" 49 .

Describing the reception of law, S. V. Tkachenko proposes to understand it as borrowing and introducing ideas, legal institutions and norms of terminology of foreign law in order to modernize the legal system, to acquire international authority or to consolidate political and economic dependence on other countries ${ }^{50}$.

Z. P. Melnyk defines the reception of law as "a unilateral, voluntary process of borrowing, accepting and further adapting to the conditions of a

${ }^{45}$ Курышев Е.Ю. Рецепция в российском праве: автореф. дисс. на соискание учен. степени канд. юрид. наук : спец. 12.00.01. Саратов, 2005. С. 12.

${ }^{46}$ Азнагулова Г. М. Рецепция права как форма взаимодействия национальных правовых систем: автореф. дисс. на соискание учен. степени канд. юрид. наук : спец. 12.00.01. Казань. 2004. С. 11.

${ }^{47}$ Мутай И.М. Рецепция и реставрация в праве. Журнал зарубежного законодательства и сравнительного правоведения. 2011. № 5. С. 55.

${ }^{48}$ Шаркова И. Н. Понятие рецепции права: неизменная сущность и новое содержание в эпоху глобализации. Журнал научных публикаций аспирантов и докторантов. 2013 URL: http://jurnal.org/articles/2013/uri106.html.

49 Приешкина Е.А. Категория рецепции в современной юридической литературе. Актуальные инновачионные исследования: наука и практика: электронное научное издание. 2011 . № 4 . http://www .actualresearch . ru/nn/2011_4/Article/index .htm.

${ }_{50}$ Ткаченко С.В. Идеологический компонент рецепции права. Юридические записки. 2014. № 2. C. 26. 
particular country of more advanced law, created at another time or in another state, with the aim of improving the functioning of its own legal system" ${ }^{51}$. V. K. Samigullin has a similar point of view, considering that the legal reception should mean borrowing and perception that occur in the process of interaction of different legal systems over a considerable period ${ }^{52}$.

Despite the existence of classical approaches to the modern understanding of the reception as the process of borrowing, continuity and perception, it is possible to agree with some exceptions in general, but there is a number of quite original interpretations of the studied legal phenomenon in the legal literature.

For example, N. V. Parshkova believes that the reception is a way of harmonization, which is manifested in the fact that not the law of a particular state is perceived, but the experience of developed legal systems. The aim is not only to reorganize the legal order but also the achievement of rapprochement, that is, the harmonization of national law with that of the other states, since differences in law impede the interaction between them. While in the process of harmonization, the researcher assumes the role of the reception as a "link between legal systems" ${ }^{53}$. Despite all the originality, such an understanding of the reception is quite debatable, since it raises a number of questions, for example, it is unclear what the researcher understands by the "experience of developed legal systems? What legal systems does she consider to be developed? Finally, how will harmonization happen if an "experience" but not the law will be perceived?

The radical position with the negative connotation is expressed by $\mathrm{M}$. Yu. Ryazanov, who consider the phenomenon to be the process of borrowing foreign legal experience, abstracted from the peculiarities of the national mentality, which led to the break with the Slavic legal culture and the formation of legal nihilism ${ }^{54}$. Such interpretation of the reception cannot be agreed at all, because in fact, the researcher considers only one type of reception - I "decorative", without taking into account the positive consequences and promising trends.

51 Мельник 3.П. Рецепція як засіб вдосконалення правової системи (теоретикоправовий аспект): автореф. дисс. канд.. юрид. наук. спец. 12.00.01. К., 2009. С. 8.

52 Самигуллин В.К. О природе рецепции права. Вестник Восточной экономикоюридической гуманитарной академии. 2013. № 5 (67). С. 68.

53 Паршкова Н. В. Категория «рецепции» в современной юридической литературе. Право и государство: теория и практика : федеральный научный юридический ежемесячный журнал. М. 2012. № 7 (91). С. 24-29

${ }^{54}$ Рязанов М.Ю. Слов'янське право і слов'янська правова культура: загальнотеоретичний аспект. Автореф. дис. ... кандидата юридичних наук за спеціальністю 12.00 .01 «Теорія та історія держави і права; історія політичних і правових учень». - Національний університет «Одеська юридична академія», Одеса, 2013. С. 6. 
K. A. Zhebrovska considers the reception to be a way of universalization of the national law $^{55}$. The researcher thinks that the reception is the perception, recognition and approval of the national legal system of rules and principles of the supranational law, aimed at the universalization of the national law. This definition is also debatable because in this case one of the types of reception - forced - is under consideration.

A rather original position on the understanding and interpretation of "the reception of the right" was expressed by V. O. Rybakov. According to his position: "... the reception of the right is a sanctioned law-making, based on the legal material of other countries. The inclusion of the reception in the law-making process is a kind of protective mechanism against the direct invasion of third-party norms into the sovereign national system of law. For this method of law development to be effective, it is necessary to take into account the similarity of the types of law involved, to evaluate the limits of coincidence of the subject of their legal regulation, the systemic nature of law, as well as to have complete information on the practice of borrowed legal material ${ }^{56}$.

The mechanical nature of the reception as a basic feature is the basis for its understanding according to M. O. Pshenychnov. In his opinion the reception is a form of international legal harmonization of legislation under which he understands the adoption by the state of rules of the national law, which textually replicate the rules of the international law, specify and adapt them to the peculiarities of the social system and legal system. The reception, as the researcher considers, is possible only in the rulemaking process, because in this way the international legal model is borrowed without changing its shape and internal logical construction ${ }^{57}$.

V. O. Letyaev insists on understanding the reception as the process of borrowing legal experience related to the systematization of legal norms ${ }^{58}$. The scientists also regards the reception just as a methodological tool of lawmaking. L. V. Sokolska suggests the original approach, offering to understand the reception as "a kind of historical form of legal acculturation" and to define it "... as a unilateral process of transferring elements of the legal system of the

\footnotetext{
55 Жебровська К.А. Правові цінності у взаємодії правових систем : дисс. ... кандидата юридичних наук спеціальність: 12.00.01. Одеса, 2017. С. 60.

${ }_{56}$ Рыбаков В. А. Преемственность в отечественном праве в переходный период: общетеоретические вопросы : Автореферат диссертации на соискание ученой степени доктора юридических наук. Специальность 12.00.01. Омск, 2009. С. 9.

57 Пшеничнов М.А. Гармонизация российского законодательства (теория, практика, техника): автореф. дисс. доктора юрид. наук. спец. 12.00.01. Нижний Новгород, 2011. C. 50; Пшеничнов М.А. К вопросу о формах международно-правовой гармонизации российского законодательства. Вестник Нижегородской академии МВД России. 2013. № 24. C. 21.

58 Летяев В.О. Систематизация законодательства и рецепция в праве: закономерности взаимодействия. Вестник Саратовской государственной академии права. 2009. № 4. С. 140.
} 
donor society with the obligatory assimilation of the recipient society. In addition, the initiator of the reception is a party wishing to implement a partially or fully the legal system of the donor. The donor, however, is usually indifferent to such a borrowing process" ${ }^{\prime 59}$. Of course, the position is quite interesting from a scientific point of view, but the logical question arises, if the donor is indifferent to this process, how the condition of "obligatory" in the process of assimilation by the recipient will be realized?

L. A. Ackerman has the opposite point of view and regards the reception as "... one of the options of acculturation, but one that has been given some independence" ${ }^{60}$. That is, the researcher considers the reception as the global acculturation in which the national legal system is being changed, there are profound changes in the legal culture, global borrowing of elements of foreign law - its essence, system or structural elements (industries, institutions) ${ }^{61}$.

There is also the opinion that the borrowed norm plays the role of a kind of "enzyme" and promotes the transformation of the whole institution, either by literally copying what is abroad or, more often, by synthesizing elements of the national and foreign law. The mechanism of influence may be different precisely because the features of socio-cultural development of the West and East of Europe are also different. These features, as well as differences in the legal mentality of European countries, largely influence the peculiarities of the reception processes of law in different countries ${ }^{62}$.

Summarising research findings made by scholars in the field of state theory and law, it can be stated that mainly the reception is considered as the process of borrowing, perception and continuity, etc. But there is also a variety of quite original positions, although they all significantly narrow the content of the studied legal category, don not consider all semantic aspects of the phenomenon and in some cases the scientists even deny the characteristics.

In foreign legal doctrine, the reception is mainly regarded in historical context as the reception of Roman law, in particular the importance of the reception of Roman law for Western Europe, emphasized by F. C. Savigny ${ }^{63}$. The German lawyer F. Pringscheim thinks that understanding the concept of the reception is quite voluminous, so it is easier to determine what the concept does not mean. He also noted that not only the alien scientific

59 Сокольская Л.В. Виды правовой аккультурации. Научные труды МГЮА. 2009. № 6. С. 1289.

60 Акерман Л. А. Рецепція права та правова акультурація. Актуальні проблеми держави і права. 2005. Вип. 25. С. 131. URL: http://nbuv.gov.ua/UJRN/apdp_2005_25_30.

${ }^{61}$ Ibid.

${ }^{62}$ Макарова И. В. Влияние римского права на становление института обязательственного права России :Вопросы истории и теории : автореферат диссертации ... кандидата юридических наук. Специальность 12.00.01. Волгоград, 2005. С. 20. Bd. 1-7;

${ }^{63}$ Savigny F. C. Geschichte des romischen Rechts im Mittelalter. Heidelberg, 1834-1851. 
method or another's philosophical and legal world view is reciprocated, but also another's right ${ }^{64}$.

Wolfgang Wiegand believes that the term "reception" is used to refer to the integration of foreign ideas and ways of thinking. Using the terminology "reception of the American law", he draws an analogy with the process of the spread of Roman law as an ius commune throughout the whole Europe in the 12th-16th centuries. In his study, he notes that there is a striking parallel between the process by which Roman law took root in Italian universities in the Middle Ages and turned into European ius commune on the one hand, and the spread of the American law on the other ${ }^{65}$.

Jean-Michel Klett notes that the reception of foreign law is a practice that exists in almost all legal cultures. In particular, in the area of commercial law, they predominantly use the US approach, as in the state there is a substantial legal experience borrowed from other countries ${ }^{66}$.

For the first time in the general context, Jan von Hein considers the reception of US company law in Germany, and the author believes that such factors as legal culture, political or economic situation in the country may interfere with the reception process ${ }^{67}$.

Polish scientist Yu. Bardakh considers the reception as "... borrowing, assimilation of alien cultural models by a certain society" ${ }^{\prime 68}$.

In foreign legal doctrine the study of the reception of the right conducted by R. Robertson and F. Lechner is worth while discussing. They state that the understanding of the reception of the specifics is gradually being asserted, which consists in the fact that not only national legal systems but as donors and recipients are meant. Individual states and the European Union are recognized as the subjects of the reception as well. Consequently, the reception is increasingly understood as the form of the Europeanisation of law. In this connection, it is of particular interest that the use of the new concept allows to expand the range of countries involved in the process of the European integration. This assumption is confirmed by the practice of using this concept to describe the possibilities of borrowing (reception) of the legal experience of the European Union by the non-EU countries. Different types of reception (formal, behavioural, communicative, discursive), which depend on the nature of the international institutions involved in the

\footnotetext{
${ }^{64}$ Pringscheim F., Reception, în Revue internationale des droits de l’Antiquité, 2009, vol. 8, p. 244-245.

${ }^{65}$ Wiegand W. The Reception of American Law in Europe/ The American Journal of Comparative Law. 1991. Volume XXXIX. № 2. P. 229-230.

${ }^{66}$ Klett J.-M. Die Trust-Struktur im Vertragsmodell des Investmentrechts Berlin: Duncker \& Humblot, 2015. 243 p.

${ }^{67}$ Jan von Hein Die Rezeption US-amerikanischen Gesellschaftsrechts in Deutschland, 20081089 Seiten.

${ }^{68}$ Bardach J. La reception dans l'histoire de l'etat et du droit. Le droit romain et sa reception en Europe. Varsovie, 1978. P. 27.
} 
reception process, are also specified to predict the implementation of these opportunities. The reception itself is classified in two dimensions: the probability of a non-EU recipient country adopting its reception as well as the implementation and enforcement of these rules, which is key to assessing the EU's internal policy impact, i.e. the results of the reception ${ }^{69}$.

Thus, it can be noted that there is a lack of scholarly attention to study of the reception, and its understanding is mainly associated with the restoration of Roman law in the modern law, although there are researches on reception as the process of borrowing and perception. Mostly foreign scholars are adherents of the theory of "legal transplantation" or "legal borrowing" as well as other ideas of "legal displacement", "legal migration", "legal contamination", "legal stimuli" and others.

\section{Reception in constitutional law: basic approaches and doctrinal interpretations}

In constitutional law, the constitutionalist scholars give little attention to the problems of the reception. Although in the context of constitutional and legal modernization in Ukraine this issue is of particular relevance. As V. V. Kochetkov rightly points out: "... speaking of one form or another of constitutionalism, we analyse the process of the reception of constitutional public-law institutions in a specific system of state law and the features of rationalization of archetypes of constitutional justice in legal doctrine" ${ }^{70}$.

In modern constitutional law, scientists are mainly considering the need for the reception (or some of its methods of transformation, harmonization, adaptation, implementation, etc.) in the context of the European integration processes, which significantly narrows the understanding of the essence of this phenomenon. Thus, M. O. Pshenychnov notes that the constitutional reception of international law eliminates changes in the content of norms that promote approximation, unification of national legal systems governing similar relations. This is mostly relevant to the problems of human survival in the context of the global threats such as the proliferation of nuclear weapons, environmental disasters, etc.. The solution of the problems depends on the existence of coordinated and unified actions of many states ${ }^{71}$.

Ilchenko T. Yu. supposes the constitutional reception to be the process of borrowing and the perception of pan-European constitutional values. The researcher warns that the transfer of constitutional values to "churlish soil" can

\footnotetext{
${ }^{69}$ Robertson R., Lechner F. Modernization, Globalization and the Problem of Culture in the World-Systems Theory. Theory, Culture \& Society. 1985. № 2. P. 103-117.

${ }^{70}$ Кочетков В.В. Конституционализм и архетипы русской власти (cacus 1906 года). Российский журнал правовых исследований. 2015. № 1 (2). С. 156.

71 Пшеничнов М.А. К вопросу о формах международно-правовой гармонизации российского законодательства. Вестник Нижегородской академии МВД России. 2013. № 24. C. 21.
} 
lead to negative consequences, to their deformation, to the formation of distorted ideas about democratic institutions, legal nihilism, absolutization of power, and as a consequence - disappointment of the population in these institutions ${ }^{72}$.

The low level of constitutional culture, the systemic inadequacy of the mechanisms of securing the rule of law, the existence of an internally contradictory legal system, the lack of a unified value-systematic understanding of the social guidelines of social development also encourages negative consequences.

Anichkin E. S. and Kokina M. N. uphold the position of understanding the reception in constitutionalism as borrowing from national or foreign experience $^{73}$.

Some scholars in the field of constitutional law propose to consider the reception solely in the sense of borrowing. I. O. Hosha supposes that "... reception is the process of borrowing the right system of the recipient, elements of the legal system of the donor and it can serve as an instrument for improvement, modernization of law, a mean of interaction of legal systems" ${ }^{74}$. In addition, the researcher actually reduces the understanding of the reception to "the consequence of harmonization", which is possible only if the legal systems are in the same system of legal values, which are expressed in the relevant principles ${ }^{75}$.

While researching the reception in constitutional law, A. I. Dudko suggests to imagine the phenomenon as a process of borrowing the legal system (the recipient) and elements of another legal system (the donor). At the same time, the author emphasizes that in the case of a prudent approach to the transfer of models of the constitutional and political order of one state to other states, the reception acts as an instrument for the improvement of constitutional $\operatorname{law}^{76}$. V. I. Lafitskyi also emphasizes the understanding of the reception as borrowing the constitutional models of other states, which is the main instrument of the impact of globalization on the constitutional order ${ }^{77}$.

\footnotetext{
${ }^{72}$ Ильченко, Т. Ю. Рецепция российской конституции. Право и государство: теория и практика. 2015. № 9. С. 48-49.

${ }^{73}$ Аничкин Е. С., Кокина М. Н. Виды рецепции в российском конституционализме. Евразийский юридический журнал. № 5 (84) 2015. С. 125-127.

${ }^{74}$ Гоша I.О. Конституційно-правове забезпечення гармонізації законодавства України із законодавством ЄС: проблеми теорії та практики: дис. ... канд. юрид. наук: спеціальність 12.00.02. Маріуполь, 2012. С. 118.

${ }^{75}$ Ibid. C. 119.

${ }^{76}$ Дудко А.И. Рецепция в конституционном праве России: автореф. дисс. ... канд. юрид. наук : спец. 12.00.02. Челябинск, 2010. С. 9, 13.

77 Лафитский В.И. Механизмы воздействия процессов глобализации на конституционный строй // Реализация Конституции: от идей к практике развития конституционного строя (состояние и перспективы российского конституционализма на общемировом фоне). Международное исследование : сборник / Международный институт мирового развития. - М. : Издательский центр Фонда конституционных реформ, 2008. C. 311.
} 
In his research, S. A. Panasyuk concludes that "reception", "transformation" or "incorporation" are in fact the ways of implementation"78. B. A. Safarov also supposes that implementation, transformation, incorporation, reception and adaptation are the ways of fulfilling international obligations $^{79}$. The doctrinal position of M. O. Baimuratov implies an understanding of the reception as a way (form) of harmonization of constitutional law of Ukraine with the international $\operatorname{law}^{80}$.The acceptable for us in the opinion of V. V. Manturov. According to his thought such phenomena as "borrowing", "adaptation" and "perceptions", considered in a narrow sense, to be referred to the parts of large-scale process of "the reception" of law. In a broad sense, the author proposes to understand the reception as the complex process, involving not only the transposition of the rules (that is, their borrowing), but also the process of implementation of these rules by the legal system of the recipient ${ }^{81}$.

Savchyn M. V. considers the problem of constitutional borrowing in the fact that they are close to the problem of copying specific constitutional institutions and systemic constituent elements, which is debatable ${ }^{82}$.

According to V. V. Homonai, "... the reception is first of all the complex process that is not referred to a mechanical transposition of certain normative provisions, but also it involves the further assimilation and use of ideas, principles, institutions, etc. of the legal system of other times and other peoples" 83 .

Indeed, by ratifying certain international agreements, the Parliament of Ukraine, on behalf of the State, actually agrees to their implementation into the national law and it is obliged to textually reiterate the provisions set out therein, thus harmonizing, adapting or transforming domestic legislation to EU law.

I. V. Kenenova believes that borrowing of the constitutional and legal experience does not always require prior sophisticated research into its usage. The researcher finds the justification of such a position in the "instrumental approach" and insists: "... it is necessary to borrow only legal

${ }^{78}$ Панасюк С.А. Принципи європейської хартії місцевого самоврядування та актуальні проблеми їх імплементації в законодавство України : дис. ... кандидата юридичних наук спец.: 12.00.02. Маріуполь, 2015. С. 158.

79 Сафаров Б.А. История воплощения концепций и международных стандартов в области прав человека в правовую систему Республики Таджикистан: дисс. ... д-ра юрид. наук. спец. 12.00.01. Душанбе, 2015. С. 165.

${ }^{80}$ Баймуратов М. А. Международное публичное право : учебник. Х. : Одиссей, 2003. C. $18-19$.

${ }^{81}$ Мантуров В.В. Соотношение рецепции и иных форм правовых заимствований. Сибирский юридический вестник. 2012. № 4(59). С. 108-109.

${ }^{82}$ Савчин М.В. Конституціоналізм і природа конституції: монографія. Ужгород: Поліграфцентр «Ліра», 2009. С. 46.

${ }^{83}$ Гомонай В.В. Рецепція права як фактор євроінтеграційних процесів. Порівняльноаналітичне право. 2013. № 1. С. 11. 
instruments that do not have obvious ideological or traditional "colouring" 84 . Namely, it is proposed to borrow only: 1) logical moves that are used in the construction of the legal norms, institutions, as well as to build the argumentation provided in the justification of legal decisions that have proven effective; 2) methods of systematization of legal material and organization of law enforcement practices (acceptable to relevant social or professional groups); 3) ways of implementing universal norms and principles of constitutional law ${ }^{85}$.

According to our opinion, it is quite a debatable idea, since if one does not directly borrow from the constitutional-legal norms, institutions, doctrines that have proven their effectiveness in the process of functioning, is it possible that the reception then contributes to the development of a system of constitutionalism? Therefore, we convince that we should not focus on a just "instrumental" approach, since it significantly impairs the substantive content of the reception (at least borrowing as one of its forms) as a constitutional and legal phenomenon.

Summarising research findings, it can be noted that in the constitutional law of Ukraine the concept of the reception is reduced to transfer or borrowing, which significantly impairs the substantive content and semantic meaning of this legal category. It is believed that the reception itself from the point of view of law is an ideologically neutral, mechanical act, which can be based on a variety of reasons and a diverse ideological base ${ }^{86}$, but this approach poses certain threats and can ultimately lead to various constitutional and legal distortions.

Thus, from the foregoing it becomes obvious the relevance, lack of research and doctrinal uncertainty in the interpretation of the reception in general and the reception in constitutional law, in particular.

Constitutional law is a leading public-law branch of the national system of law, and the peculiarity of constitutional norms, as L. O. Murashko notes, is the ability to integrate social relations, distinguishing their most stable types. In this connection, these norms are characterized by a high degree of generalization of the possible or proper behaviour of the subjects of law, legal guidelines, specific value-oriented rules for the state building ${ }^{87}$. Therefore, the importance and necessity of studying the reception in constitutional law is related, first, to the specifics of constitutional legal

${ }^{84}$ Кененова И.В. Некоторые современные проблемы преподавания конституционного права зарубежных стран. Вестник Московского университета. Серия Право. 2010. № 1. C. 112 .

${ }^{85}$ Ibid. C. $112-113$.

86 Мутай И.М. Рецепция и реставрация в праве. Журнал зарубежного законодательства и сравнительного правоведения. 2011. № 5. С. 57.

${ }^{87}$ Мурашко Л.Г. Аксиологическое измерение процесса правообразования: история и современность. Автореф. дисс. доктора юридических наук. Спец. 12.00.01. М., 2015. С. 34. 
norms, which, unlike the norms of other branches, determine the normativevalue guidelines and influence the constitutional activity of the subjects of constitutional-legal relations. The regulatory capacity of other branches is to promote the observance of axiological constitutional guidelines and to strive for their implementation.

Increasingly, researchers point to the gradual internationalization of constitutional law, that is, the threat that constitutional law ceases to be national and authentic. In particular, R. Goodin points out that "... reading large volumes of constitutional texts strikes the similarity of their language; reading the history of the constitution of any country, it is striking how large the amount of conscious borrowing is" ${ }^{88}$.

Saunders Ch. also highlights the linguistic and substantive similarity of the constitutions of different countries, and studies of the history of their creation indicate that they originate from each other, but must conform to the value system of the society for which constitutional principles and norms are intended. Otherwise, they will remain on paper and will not be realized in practice or become a reality. Moreover, inconsistency with the value system of the reality can lead them to change from a stimulus for innovation of the social sphere to the source of deep social contradictions or an instrument of coercion of the authorities ${ }^{89}$.

We would like to highlight that the Constitution is a special system of values specific to a proper social community, with its specific features, problems and approaches to solving them. This does not mean absolutization or ossification. It would be impossible to ignore the general principles, best international practices, requirements of the international law, international case law and international constitutional culture ${ }^{90}$.

To ensure systemic progress it is important to try to harmonize all of the above with own value system instead of mechanical replication. As V. Osiatynskyi rightly states, borrowing is inevitable because there are universal constitutional principles and mechanisms that were known in the past, they are universally recognized and act as so-called standards or norms and principles of international law ${ }^{91}$.

While carrying out the technical and textual transfer of constitutional legal norms from the donor country to the recipient country, it should be considered that the existence of each norm or institute is the embodiment of

${ }^{88}$ Goodin R. Designing Constitutions: the Political Constitution of a Mixed Commonwealth. Constitutionalism and Transformation: European and Theoretical Perspectives / Ed. by R. Bellamy, D. Castiglione. Blackwell, 1996. P. 223.

${ }^{89}$ Saunders Ch. A. Constitutional Culture in Tradition. Constitotional Cultures. Ed. by M. Wyrzykowski. Warsaw, ISP, 2000. P. 41-42

${ }^{90}$ Harutyunian G. Constitutional culture: the lessons of history and the challenges of time. Yerevan: Revised English edition. 2009. P. 115.

${ }_{91}$ Осятынский В. Парадоксы конституционного заимствования. Сравнительное конституичионное право. 2004.№ 3. С. 53. 
the constitutional traditions, values, ideology and national mentality. Therefore carrying out the reception it is worth to be conscious about the process taking into account the specifics of the constitutional development of a particular state.

\section{CONCLUSIONS}

Summarising research findings, it can be noted that in the legal literature the reception is understood as "borrowing of foreign law", "the process of perception and adaptation to the prescriptions of law of a particular country, produced in another state or in a previous historical era", "historical form of legal acculturation". There are thoughts about understanding the reception "as a borrowing system of general views of individual communities of the society or society as a whole as for the foundations (principles) of social, political and legal order". In addition, the reception is understood as "an organized form of legal borrowing in the process of implementation of which scientific approach is used in the form of comparative justification for the transfer of the legal elements from one national legal environment to another". Besides the phenomenon can be considered as "an assimilation by a society of another cultural models" or "a way of harmonizing norms of international law and national constitutional law".

The analysed doctrinal interpretations of the reception as a legal phenomenon allow us to highlight the polysemanticity and heterogeneity of this category. Meanwhile, in the constitutional law, the lack of comprehensive studies of this issue adversely affects both the development of the functioning of the reception mechanism as a whole and the effectiveness of implementing a qualitatively updated model of the entire constitutional mechanism of public power.

Constitutional law science must synthesize and develop traditional theories of the legal reception, which will result in the development of a modernized doctrine of the reception in constitutional law. Today, the development of scientific and technological progress and global challenges to the humanity (demographic, environmental, terrorist, etc.) have raised the issue of changing the era of legal thinking and need to modernize the doctrine of constitutionalism as a whole. These processes imply the need for close cooperation between states, which further strengthens their interconnection, requires the development of supranational institutions and the convergence of legal systems.

The reception in constitutional law, of course, has a dramatic political and legal connotation and it is directly dependent on constitutional justice and constitutional culture, since the success of the reforms carried out will remain only an imitation of constitutionalism if the society does not accept them and adhere to them. 


\section{SUMMARY}

The article deals with the systematic research and formation of a holistic view of the reception in constitutional law allowed to determine its essence as a political and legal phenomenon. Also the term "reception" has been widely used in the scientific discourse, not only in legal science, but also in philology, cultural studies, psychology, literature, linguistics, music, history and others. Summarising research findings defined the analysed doctrinal interpretations of the reception as a legal phenomenon allow us to highlight the polysemanticity and heterogeneity of this category. Meanwhile, in the constitutional law, the lack of comprehensive studies of this issue adversely affects both the development of the functioning of the reception mechanism as a whole and the effectiveness of implementing a qualitatively updated model of the entire constitutional mechanism of public power.

\section{REFERENCES}

1. Kahn-Freund O. On Uses and Misuses of Comparative Law. The Modern Law Review. 1974.Vol. 37, No. 1 (Jan.). P. 1-27.

2. Watson, A. Legal Origins and Legal Change, London ; Rio Grande, Ohio, USA : Hambledon Press, 1991. 321 p.

3. Конституція України від 28 червня 1996 p. https://zakon.rada. gov.ua/laws/show/254к/96-вр.

4. Словарь иностранных слов. 18-е изд., стереотип. М. : Рус. яз., 1989. $622 \mathrm{c}$.

5. Словник української мови : [в 11 т.] / [ред. кол.: І.К. Білодід (гол.) та ін.] ; АН УРСР, Ін-т мовознавства ім. О.О. Потебні. К.: Наукова думка, 1970-1980. Т. 7. 1976. 723 с.

6. Новейший словарь иностранных слов и выражений. Мн.: Совр. лит., 2007. 976 с.

7. Словник іншомовних слів / За ред. О. С. Мельничука. Київ : Головна редакція УРЕ, 1974. $775 \mathrm{c}$.

8. Бродовська В. Й., Грушевський В. О., Патрик І. П. Тлумачний російсько-український словник психологічних термінів: словник. К.: ВД "Професіонал», 2007. 512 с.

9. Гончарук Р. А. Читацька рецепція як складова літературної комунікації. Наукові записки нду ім. М. Гоголя. Філологічні науки. 2016. Книга 2. С. 27-31.

10. Хамедова О. Б. Антоненко-Давидович: доля, творчість, критична рецепція : автореф. дис. ... канд. філол. наук : 10.01.01. Харків, 2008. $20 \mathrm{c}$.

11. Левакин Н.Н. Художественная рецепция как литературоведческое понятие (к вопросу понимания термина). Известия ПГЛУ им. В.Г. Белинского. 2012. № 27. С. 308-310. 
12. Сімонок В. П. Лексико-семантична рецепція іншомовної лексики в українській мовній картині світу. Автореф. дисс. ... доктора філологічних наук за спеціальністю 10.02.01. Харків, 2002. 25 с.

13. Підкамінна Л.В. Епітет Т.Г. Шевченка: генеза, структура i сучасна мовна рецепція. Автореферат дисертація ... кандидата філологічних наук за спеціальністю 10.02.01 «Українська мова». Національний педагогічний університет імені М.П. Драгоманова, м. Київ, 2011. 19 с.

14. Поляшенко Т.В. Рецепція звичаєвого права в сучасній українській культурі: дисертація ... кандидата культурології за спеціальністю 26.00.01 - «Теорія та історія культури». К., 2009. 17 с.

15. Летина Н.Н. Теоретические основания рецепции в провинциальном искусстве. Регионология. 2008. № 3. С. 295-302.

16. Міхно О. Типологія школярів Петра Лесгафта та ії рецепція українськими вченими. Рідна школа. 2016. № 7. С. 61-68.

17. Олексів Я. Рецепція жанрів сюїти і партити в українській баянній музиці другої половини XX ст. : автореф. дис. ... канд. мистецтвознав. : 17.00.03 Львів, 2011. $20 \mathrm{c.}$

18. Олійник С. Ф. Регіональна рецепція музичної творчості (на прикладі творчості Ф. Шопена, Р. Вагнера і Ф. Ліста в музичній культурі Львова) : Дисертація ... кандидата мистецтвознавства за спеціальністю 17.00.03. Львів, 2018. 195 с.

19. Куций Іван Петрович. Українська науково-історична думка Галичини (1830-1894 рр.): рецепція національної історії. Тернопіль: Джура, 2006. 220 c.

20. Мотренко Т. Рецепція гегелівських ідей у світоглядно-релігійній парадигмі російської філософії XIX - початку XX століть : автореф. дис. ... д-ра філос. наук : 09.00.05. Київ, 2004. 37 с.

21. Большая советская энциклопедия. Под ред. А. М. Прохорова. М.: Изд-во «Советская энциклопедия», 1975. Т. 22. С.67.

22. Большой юридический словарь. Додонов В. Н., Ермаков В. Д., Крылова М. А. и др. М.: 2001. 790 с.

23. Словарь международного права. [С. Б. Бацанов, Г. К. Ефимов, В. И. Кузнецов и др.]. 2-е изд. М.: Международные отношения, 1986. $432 \mathrm{c}$.

24. Тихомирова Л. В., Тихомиров М. Ю. Юридическая энциклопедия. М. : Юринформцентр, 2002. 972 с.

25. Саидов А.Х. Сравнительное правоведение (основные правовые системы современности): Учебник / Под ред. В.А. Туманова. М.: Юристь, 2003. 448 с.

26. Wieacker F. The importance of roman law for western civilization and western legal thought. Boston College International and Comparative Law Review. 1981. Vol. 4. № 2. P. 257-281. 
27. Томсинов В. А. О сущности явления, называемого «рецепцией римского права» / в кн. Виноградов П. Г. Очерки по теории права. Римское право в средневековой Европе / Под редакцией и с биографическим очерком У. Э. Батлера и В. А. Томсинова. М.: Издательство «Зерцало», 2010. С. 262-279.

28. Косарев А.И.. Римское частное право. М.: Юриспруденция, 2007. 192 c.

29. Шала Л. В. Концепція приватної власності у римському праві та iii рецепція у праві України. Автореф. дисертації ... кандидата юридичних наук за спец. 12.00.01, Львів, 2010. 19 с.

30. Підопригора, О.А., Харитонов, Є.О. Римське право : підруч. 2-ге вид. К. : Юрінком Інтер, 2009. 528 с.

31. Фіночко Ф. Д. Роль рецепції римського права у формуванні європейських традицій адміністративного права Вісник Харківського національного університету внутрішніх справ. 2007. № 38. С. 24-31. URL: http://nbuv.gov.ua/UJRN/VKhnuvs_2007_38_6.

32. Денисова Е.М. Проблема рецепции римского права в России. Вестник ТвГУ. Серия. Право. 2012. Вып. 32. С. 328-336.

33. Паршкова Н.В. Определение преемственности в рецепции права: общетеортетический аспект. Вопросы современной юриспруденции: сб. ст. по матер. VIII междунар. науч.-практ. конф. Новосибирск: СибАК, 2012. URL: https://sibac.info/conf/law/viii/26094.

34. Егоров А.В. Сравнительное правоведение и правовая рецепция. Вестник Полоцкого государственного университета. Серия D. Экономические и юридические науки. 2013. № 6. С. 164-167.

35. Харитонов $€$., Харитонова О. Від осмислення рецепції римського права - до формування загальної теорії взаємодії правових систем. Право України. 2014. С. 274-293.

36. Харитонов Є.О. Методологічні засади дослідження проблем правової адаптації України до внутрішнього ринку ЄС. Наукові пращуі Національного університету «Одеська юридична академія». Т. 17. / голов. ред. М.В. Афанасьєва; МОН України, НУ «ОЮА». Одеса : Юрид. л-ра, 2015. С. 232-270.

37. Черниловский 3.М. Русская Правда в свете других славянских судебников // Древняя Русь: проблемы права и правовой идеологии : Сб. науч. тр. / Всесоюз. юрид. заоч. ин-т; [Отв. ред. Г. В. Швеков]. М.: ВЮЗИ, 1984. 116 с.

38. Лафитский В.И. Сравнительное правоведение в образах права. Том первый. М.: Статут, 2010. 429 с.

39. Скоробогатов А. В. Правовые заимствования как средство совершенствования национальной правовой системы. Актуальные проблемы экономики и права. 2018. Т. 12, № 1. С. 77-88. 
40. Фольгерова, Ю. Н. Преемственность и рецепция в конкурсном процессе стран Западной Европы и России: Историко-сравнительный анализ: автореф. дис. на соискание уч. степени канд. юр. наук. спец 12.00.01 «Теория и история права и государства; История учений о праве и государстве». Саратов, 2008. 19 с.

41. Авраменко Л.В. Розмежування наступності у праві 3 іншими суміжними поняттями. Проблеми законності. 2012. № 121. С 3-13.

42. Курышев Е.Ю. Рецепция в российском праве: автореф. дисс. ... канд. юрид. наук : спец. 12.00.01 Теория и история права и государства; история учений о праве и государстве. Саратов, 2005. 26 с.

43. Азнагулова Г. М. Рецепция права как форма взаимодействия национальных правовых систем: автореф. дисс. ... канд. юрид. наук : спец. 12.00.01 "Теория и история права и государства; история правовых учений». Казань, 2004. 25 с.

44. Мутай И.М. Рецепция и реставрация в праве. Журнал зарубежного законодательства и сравнительного правоведения. 2011. № 5. C. 53-64.

45. Шаркова И. Н. Понятие рецепции права: неизменная сущность и новое содержание в эпоху глобализации. Журнал научных публикаций аспирантов и докторантов. 2013. URL: http://jurnal.org/articles/2013/ uri106.html.

46. Приешкина Е.А. Категория рецепции в современной юридической литературе. Актуальные инновационные исследования: наука и практика: электронное научное издание. 2011. № 4. URL: http://www.actualresearch.ru/nn/2011_4/Article/index.htm.

47. Ткаченко С.В. Идеологический компонент рецепции права. Юридические записки. 2014. № 2. С. 21-27.

48. Мельник 3.П. Рецепція як засіб вдосконалення правової системи (теоретико-правовий аспект): автореф. дисс. ... канд.. юрид. наук. спец. 12.00.01 «Теорія та історія держави і права; історія політичних i правових вчень». К., 2009. 14 с.

49. Самигуллин В.К. О природе рецепции права. Вестник Восточной экономико-юридической гуманитарной академии. 2013. № 5 (67). C. 66-75.

50. Паршкова Н. В. Категория «рецепции» в современной юридической литературе. Право и государство: теория и практика : федеральный научный юридический ежемесячный журнал. 2012 № 7 (91). C. 24-29.

51. Рязанов М.Ю. Слов'янське право і слов'янська правова культура: загальнотеоретичний аспект. Автореф. дис. ... кандидата юридичних наук за спеціальністю 12.00.01 «Теорія та історія держави і права; історія політичних і правових учень». Одеса, 2013. 21 с. 
52. Жебровська К.А. Правові цінності у взаємодії правових систем. Дисс. ... кандидата юридичних наук за спеціальністю 12.00.01 «Теорія та історія держави і права; історія політичних і правових учень». Одеса, 2017. 222 c.

53. Рыбаков В. А. Преемственность в отечественном праве в переходный период: общетеоретические вопросы : Автореферат диссертации ... доктора юридических наук. 12.00 .01 - «Теория и история права и государства; История учений о праве и государстве». Омск, 2009. $37 \mathrm{c}$.

54. Пшеничнов М.А. Гармонизация российского законодательства (теория, практика, техника): автореф. дисс. ... доктора юрид. наук. спец. 12.00 .01 «Теория и история права и государства; история учений о праве и государстве». Нижний Новгород, 2011. 58 с.

55. Пшеничнов М.А. К вопросу о формах международно-правовой гармонизации российского законодательства. Вестник Нижегородской академии МВД России. 2013. № 24. С. 20-24.

56. Летяев В.О. Систематизация законодательства и рецепция в праве: закономерности взаимодействия. Вестник Саратовской государственной академии права. 2009. № 4. С. 140-146.

57. Сокольская Л.В. Виды правовой аккультурации. Научные труды МГЮА. 2009. № 6. С. 1287-1296.

58. Акерман Л. А. Рецепція права та правова акультурація. Актуальні проблеми держави і права. 2005. Вип. 25. С. 128-131. URL: http://nbuv.gov.ua/UJRN/apdp_2005_25_30.

59. Макарова И. В. Влияние римского права на становление института обязательственного права России: Вопросы истории и теории : автореферат диссертации ... кандидата юридических наук. Специальность 12.00.01 "Теория и история права и государства; История учений о праве и государстве». Волгоград, 2005. 26 с.

60. Savigny F. C. Geschichte des romischen Rechts im Mittelalter. Heidelberg, 1834-1851. Bd. 1-7;

61. Pringscheim F., Reception, în Revue internationale des droits de l’Antiquité, 2009, vol. 8, p. 244-245.

62. Wiegand W. The Reception of American Law in Europe. The American Journal of Comparative Law. 1991. Volume XXXIX. № 2. P. 229-248.

63. Klett J.-M. Die Trust-Struktur im Vertragsmodell des Investmentrechts Berlin: Duncker \& Humblot, 2015. 243 p.

64. Jan von Hein Die Rezeption US-amerikanischen Gesellschaftsrechts in Deutschland, 2008. 1089 Seiten.

65. Bardach J. La reception dans l'histoire de l'etat et du droit. Le droit romain et sa reception en Europe. Varsovie, 1978. P. 27. 
66. Robertson R., Lechner F. Modernization, Globalization and the Problem of Culture in the World-Systems Theory. Theory, Culture \& Society. 1985. № 2. P. 103-117.

67. Кочетков В.В. Конституционализм и архетипы русской власти (cacus 1906 года). Российский журнал правовых исследований. 2015. № 1 (2). C. 155-163.

68. Пшеничнов М.А. К вопросу о формах международно-правовой гармонизации российского законодательства. Вестник Нижегородской академии МВД России. 2013. № 24. С. 20-24.

69. Ильченко, Т. Ю. Рецепция российской конституции. Право и государство: теория и практика. 2015. № 9. С. 47-50.

70. Аничкин Е. С., Кокина М. Н. Виды рецепции в российском конституционализме. Евразийский юридический журнал № 5 (84) 2015. C. $125-127$.

71.Гоша I.O. Конституційно-правове забезпечення гармонізації законодавства України із законодавством СС: проблеми теорії та практики: дис. ... канд. юрид. наук: спеціальність 12.00 .02 «Конституційне право; муніципальне право». Маріуполь, 2012. 193 с.

72. Дудко А.И. Рецепция в конституционном праве России: автореф. дисс. ... канд. юрид. наук : спец. 12.00 .02 «Конституционное право; муниципальное право». Челябинск, 2010. 26 с.

73. Лафитский В.И. Механизмы воздействия процессов глобализации на конституционный строй / Реализация Конституции: от идей к практике развития конституционного строя (состояние и перспективы российского конституционализма на общемировом фоне). Международное исследование : сборник / Международный институт мирового развития. М. : Издательский центр Фонда конституционных реформ, $2008.320 \mathrm{c}$.

74. Панасюк С.А. Принципи європейської хартії місцевого самоврядування та актуальні проблеми їх імплементації в законодавство України дисертація ... кандидата юридичних наук спец.: 12.00 .02 «Конституційне право; муніципальне право». Маріуполь, 2015. 214 с.

75. Сафаров Б.А. История воплощения концепций и международных стандартов в области прав человека в правовую систему Республики Таджикистан: дисс. д-ра юрид. наук. спец. 12.00.01 «Теория и история права и государства; история учений о праве и государстве». Душанбе, $2015.359 \mathrm{c}$.

76. Баймуратов М. А. Международное публичное право: учебник. Х.: Одиссей, 2003. 752 с.

77. Мантуров В.В. Соотношение рецепции и иных форм правовых заимствований. Сибирский юридический вестник. 2012. № 4(59). C. 104-109. 
78. Савчин М.В. Конституціоналізм i природа конституції: монографія. Ужгород: Поліграфцентр «Ліра», 2009. 372 с.

79. Гомонай В.В. Рецепція права як фактор євроінтеграційних процесів. Порівняльно-аналітичне право. 2013. № 1. С. 8-14.

80. Кененова И.В. Некоторые современные проблемы преподавания конституционного права зарубежных стран. Вестник Московского университета. Серия Право. 2010. № 1. С. 109-120.

81. Мутай И.М. Рецепция и реставрация в праве. Журнал зарубежного законодательства и сравнительного правоведения. 2011. № 5. C. 53-64.

82. Мурашко Л.Г. Аксиологическое измерение процесса правообразования: история и современность. Автореф. дисс. ... доктора юридических наук. Спец. 12.00.01 «Теория и история права и государства; история учений о праве и государстве». М., 2015. 41 с.

83. Goodin R. Designing Constitutions: the Political Constitution of a Mixed Commonwealth. Constitutionalism and Transformation: European and Theoretical Perspectives / Ed. by R. Bellamy, D. Castiglione. Blackwell, 1996. P. 223.

84. Saunders Ch. A. Constitutional Culture in Tradition. Constitotional Cultures. Ed. by M. Wyrzykowski. Warsaw, ISP, 2000. P. 41-42.

85. Harutyunian G. Constitutional culture: the lessons of history and the challenges of time. Yerevan: Revised English edition. 2009. 278 p.

86. Осятынский В. Парадоксы конституционного заимствования. Сравнительное конституциионное право. 2004. № 3. С. 53-67.

\section{Information about the author:} Verlos N. V.,

Candidate of Juridical Sciences, Associate Professor, Department of Constitutional and Labor Law, Zaporizhzhia National University 66, Zhukovskoho str., Zaporizhzhia, 69600, Ukraine 